\title{
$\mathrm{e}-$ 포트폴리오 활용한 성찰활동에 대한 예비교사의 인식과 교수효능감 변화
}

\section{Promoting Teaching Efficacy of Pre-service Teachers with Reflective Thinking using e-portfolio}

\author{
이수연*, 홍성연** \\ 아주대학교 교육대학원 ${ }^{*}$, 아주대학교 기초교육대학**
}

Sooyeon Lee(xiujuan@ajou.ac.kr)*, Seongyoun Hong(hsy06@ajou.ac.kr) ${ }^{* *}$

\section{요약}

교수효능감은 교사가 학생들에게 긍정적인 영향을 줄 수 있다는 자기 믿음이자 신념이다. 예비교사의 교수효능감을 증진시키는 방법 중 하나는 교수활동에 대해 성찰할 수 있는 기회를 제공하는 것이다. $\mathrm{e}^{-}$포 트폴리오는 이러한 성찰을 지원하는 효과적인 도구로 활용될 수 있다. 본 연구는 $\mathrm{e}^{-}$포트폴리오를 활용한 성찰활동이 예비교사의 교수효능감에 미치는 영향을 살펴보고, 교원양성교육과정에서 $\mathrm{e}^{-}$포트폴리오 활성 화 전략을 제안하는 것을 목적으로 하였다. 이를 위해 예비교사 35 명을 대상으로 10 주간 $\mathrm{e}-$ 포트폴리오를 활용한 교육적 성찰과 학습자료 정리활동에 참여하도록 한 후, 대응표본 $\mathrm{t}$-검정을 통해 사전·사후의 교수 효능감 변화를 분석하였다. 그 결과, 참여자의 교수효능감은 통계적으로 유의미하게 증가한 것으로 나타났 다. 참여자들은 $\mathrm{e}-$ 포트폴리오의 장점으로 다양한 성찰 유도, 학습자료의 체계적 저장, 정보의 공유 등을, 단점으로는 익숙하지 않은 활용방법과 낮은 접근성 등을 지적하였다. 연구결과를 토대로 예비교사의 교수 효능감 증진을 위한 $\mathrm{e}^{-}$포트폴리오 활성화 전략을 제안하였다.

중심어 : | 교수효능감 | e-포트폴리오 | 예비교사 | 반성적 사고 |

\section{Abstract}

The purpose of this study is to explore the strategies for application of e-portfolio for improving teaching efficacy of pre-service teachers. 35 pre-service teachers wrote reflection papers and uploaded their data to their personal e-portfolio during 10 weeks. They participated in two teaching efficacy surveys which were conducted before and after using e-portfolio. Twelve participants were interviewed regarding their experience and perceptions of e-portfolio. As the result of compared-sample tests, teaching efficacy increased statistically significantly. According to the students' interview, the pros and cons of e-portfolio were identified and the strategies for application of e-portfolio were suggested for improving teaching efficacy of pre-service teachers.

- keyword : | Teaching Efficacy | e-portfolio | Pre-service Teacher | Reflective Thinking |

* 본 논문은 이수연의 석사학위논문을 수정·보완한 것임 접수일자 : 2013년 08월 06일 수정일자 : 2013년 09월 06일
심사완료일 : 2013년 09월 23일

교신저자 : 홍성연, e-mail : hsy06@ajou.ac.kr 


\section{I. 서 론}

교수효능감은 교사가 학생들에게 긍정적인 영향을 줄 수 있다는 자기 믿음이자 신념이다. 교수효능감이 높은 교사는 수업개선에 적극적이고 교사로서의 전문 성 개발을 위해 노력하기 때문에 학생들의 학업성취도 및 학업태도에 긍정적인 영향을 미친다[1]. 따라서 교수 효능감은 교사로서의 발전가능성과 교육활동에 대한 헌신성 등을 예측하는 척도로 활용되기도 한다. 예비교 사의 교수효능감 역시 이들이 좋은 교사로 성장하기 위 한 노력 여부를 예측하는데 유용하다[2].

예비교사의 교수효능감과 관련된 연구들은 이것이 형성되는데 대학의 교육과정과 실습이 상당한 영향을 미친다고 지적하였다. 또, 교수효능감은 한 번 형성되면 쉽게 변화하지 않는다고 언급하고 있다[3][4]. 따라서 예비교사들이 긍정적인 교수효능감을 획득하도록 하는 전략을 교원양성교육과정에 포함할 필요가 있다.

이제까지 예비교사를 대상으로 한 대부분의 교수효 능감 연구들은 모의수업경험이나 교생실습과 같이 직 간접적인 교수경험이 교수효능감에 미치는 긍정적인 영향에 대해서 보고하고 있다[5-8]. 자기효능감의 개념 을 처음 제안한 Bandura[24] 역시 '성공경험'이 효능감 을 증진시킨다고 지적하였다. 그러나, 예비교사들의 수 업시연이나 교육실습 기회는 한정되어 있으며, 대부분 교원양성교육과정의 마지막 단계에서 이루어지기 때문 에 교육실습 이전의 교수효능감 형성에 대해서는 다루 고 있지 못하다. 또한, 실패를 경험했을 때 교수효능감 에 오히려 부정적인 영향을 미칠 수도 있으며, 실습 이 후 교육과정을 통한 교수효능감의 변화를 유도하기도 쉽지 않다.

교수효능감을 일종의 교사의 믿음과 신념이라고 보 았을 때, 교원양성교육과정 전반에서 예비교사들이 꾸 준히 자신의 교육관에 대해 성찰하고 교육문제에 대해 깊이 있게 사고함으로서 교수효능감을 증진할 수 있는 방안에 대해서 생각해볼 필요가 있다. 예비교사로서 자 신의 정체성을 형성하고 교사의 입장에서 교육문제에 대하여 어떻게 대처할지 반성하고 성찰하는 과정을 통 해 이들은 교사업무에 대한 간접적인 '대리경험'을 체험
할 수 있다. 또한, 교사라는 직업에 대한 자기 확신을 획득할 수 있다[9].

예비교사의 반성적 사고능력을 향상시키기 위해 활 용될 수 있는 효과적인 교사교육방법 중 하나가 '포트 폴리오'를 활용하는 것이다[15]. 교육분야에서 포트폴 리오는 교수 및 학습관련 자료 및 성과물을 정리한 것 으로 작성자의 학습, 성찰, 발달의 과정을 보여준다. 최 근 산출물의 저장과 관리를 용이하게 하고, 작성자들 간의 공유와 커뮤니케이션을 지원하는 웹기반 $\mathrm{e}^{-}$포트 폴리오의 도입이 확대되고 있다. 접근성과 편리성을 높 인 웹기반 $\mathrm{e}^{-}$포트폴리오를 교원양성교육에 활용함으로 써 예비교사들의 교직에 대한 성찰능력을 심화하고 궁 극적으로 교수효능감 증진을 유도할 수 있을 거이다.

이에 본 연구는 예비교사의 반성적 사고능력을 향상 시킬 수 있는 방안으로 $\mathrm{e}^{-}$포트폴리오 활용을 제안하고 자 한다. 포트폴리오를 개발하고 작성하는 과정을 통해 예비교사들은 반성적으로 사고하는 습관을 키우고, 문 제해결과 의사결정 능력을 발달시킬 수 있다[10]. 또한, 자신의 교육학적 지식과 경험을 재구성 해 봄으로써 스 스로 교육적 신념과 전문성에 대해 성찰할 수 있는 기 회를 가질 수 있다[11].

본 연구의 목적은 $\mathrm{e}^{-}$포트폴리오를 활용한 성찰활동 이 예비교사의 교수효능감에 미친 영향을 살펴보고 $\mathrm{e}^{-}$ 포트폴리오 활용을 증진하기 위한 활성화 전략을 탐색 하는 것이다. 이를 위해 $\mathrm{e}^{-}$포트폴리오의 활용 전후 예 비교사의 교수효능감을 비교하였으며, 학생들이 인식 하는 $\mathrm{e}^{-}$포트폴리오의 장단점을 분석하였다. 또한, 연구 결과를 토대로 예비교사의 교수효능감 증진을 위한 $\mathrm{e}^{-}$ 포트폴리오 활용전략을 제안하였다. 본 연구는 교원양 성교육에서 예비교사의 교수효능감을 증진시키는 방안 으로써 $\mathrm{e}^{-}$포트폴리오의 활용을 제고하는데 기여할 것 으로 기대된다.

\section{II. 이론적 배경}

\section{1. 교육분야에서 포트폴리오와 $\mathrm{e}-$ 포트폴리오}

포트폴리오는 개개인의 작품, 기록, 자료 등을 수집하 
거나 정리해 놓은 것을 말한다. 교육 분야에서는 포트 폴리오는 교수 및 학습 관련 자료 및 성과물, 그리고 그 과정에서 수업 및 학습에 대한 반성적 성찰을 정리한 것으로 교수자 대상의 티칭 포트폴리오와 학습자 대상 의 러닝 포트폴리오로 구분될 수 있다. 티칭 포트폴리 오는 일정기간동안 다양한 학습 환경에서 교수자의 교 수활동에 관한 정보를 체계적으로 수집한 모음집을 말 한다[12]. 이와 대비해서 러닝 포트폴리오는 학습자의 성장 및 발달과정, 능력과 성취수준, 노력 등을 볼 수 있 는 학습 자료 및 성과물들의 모음집이라고 할 수 있다[13]. 교육분야의 포트폴리오가 일반적인 포트폴리오와 다 른 점은 교수 및 학습 활동의 산출물이나 과정을 정리 하는 것을 넘어서, 이 과정에 대한 자기성찰과 숙고의 과정들이 포함되어 있다는 점이다[15]. 이를 통해 포트 폴리오를 작성한 교수자 및 학습자의 성장과 발달을 확 인할 수 있다.

최근 테크놀로지 기술의 발달과 함께 문서기반의 포 트폴리오의 내용과 자료를 디지털화 한 $\mathrm{e}^{-}$포트폴리오 의 보급이 확대되었다. 박동진 등[25]은 새롭게 등장한 $\mathrm{e}$-포트폴리오의 경우 개발자의 자기반성을 통한 성장 과 발전을 보여주는 개발 포트폴이오이자, 개발자의 전 문성 및 숙련도를 확인할 수 있는 평가 포트폴리오이 자, 결과물과 성과를 전시하는 전시 포트폴리오로서 기 능을 모두 포괄하는 복합적 특성을 지닌다고 지적하였다.

이러한 $\mathrm{e}$-포트폴리오는 문서기반 포트폴리오의 단점 인 자료의 보관, 운반, 작성, 수정, 관리 등의 불편함을 극복했을 뿐만 아니라, 애니메이션, 동영상, 음향, 사진 등 멀티미디어 자료를 활용함으로써 다양한 표현이 가 능하도록 지원할 수 있다[11]. 또한, 학습차원에서 학습 자들의 학업에 대한 자기성찰을 향상시키고, 학습조절 능력과 같은 학습방법을 습득하도록 하는데 기여하였 으며, 전공분야의 지식습득과 같이 학습과정을 효과적 으로 학습하는데 도움을 준다[26].

더불어, 블로그 형태의 $\mathrm{e}$-포트폴리오의 경우, 윕을 바 탕으로 정보의 수집 및 공유를 용이하게 하고 사용자 간의 상호작용을 촉진함으로써 자료에 대해 논의 및 성 찰기회를 제고할 뿐만 아니라, 개인적 학습을 사회적 학습으로 확장했다는 점에서 차별성이 있다[16][27].
결과적으로 문서기반 포트폴리오와 테크놀로지의 기 술이 결합하여 탄생한 $\mathrm{e}^{-}$포트폴리오는 기존 포트폴리 오가 가지고 있던 자기개발과 자료수집의 역할을 계승 함과 동시에 사회적인 상호작용을 촉진함으로서 포트 폴리오의 교육적 기능을 확대하였다고 평가할 수 있다.

\section{2. 교원양성교육에서 $\mathrm{e}-$ 포트폴리오의 활용}

$\mathrm{e}^{-}$포트폴리오는 교수자료 및 전략의 수집과 공유, 교 수활동의 체계적 관리, 교육관 확립과 수업개선을 위한 깊이 있는 성찰 기회 제공 등 예비교사의 교수전문성 향상 방법으로 점차 그 활용도가 높아지고 있다[14-17]. 교원양성교육에서 $\mathrm{e}^{-}$포트폴리오의 교육적 효과를 살펴 보면 다음과 같이 정리할 수 있다.

먼저, $\mathrm{e}^{-}$포트폴리오의 활용은 예비교사의 교육정보 화 능력과 테크놀로지 기술 향상에 도움이 된다[17]. 정 보화 기술의 발달과 더불어 다양한 매체에 대한 활용능 력이 예비교사들에게 요구되고 있다. 예비교사들은 $\mathrm{e}^{-}$ 포트폴리오를 작성함으로써 수업에서의 테크놀로지 활 용 능력이 향상되었다고 인식하였다[28].

다음으로 $\mathrm{e}^{-}$포트폴리오는 예비교사들이 전공 및 교 육학 관련 지식들을 습득하는데 도움을 줌으로써 전문 성 향상에 기여한다. 여러 선행 연구들은 예비교사의 $\mathrm{e}$-포트폴리오 활용이 학습내용을 이해하고 교육목표를 달성하는 것을 지원함으로써 교육에 긍정적인 영향을 미쳤다고 지적하였다[16][28].

마지막으로, $\mathrm{e}^{-}$포트폴리오는 예비교사들에게 교직에 관해 반성적으로 생각해볼 수 있는 다양한 성찰기회를 제공하고, 관련 자료의 저장 및 관리, 취업 준비 등을 지 원함으로써 교사로서의 전문성 신장에 긍정적인 영향 을 미치는 것으로 인식되었다[14][16].

결과적으로 $\mathrm{e}^{-}$포트폴리오는 효과적인 교수방법으로 서 예비교사들의 수행과 성장과정을 기록하고, 자기반 성의 기회를 제공함으로써 이들의 전문성 함양에 기여 할 수 있다.

\section{3. 예비교사의 교수효능감 증진}

교수효능감은 교사가 학습자의 학습에 긍정적인 영 향을 미칠 수 있는 교사 자신의 능력에 대한 신념을 말 
한다. 교수효능감이 높은 교사들은 그렇지 않은 교사들 에 비해 수업을 개선하는데 더욱 적극적이고 헌신적이 기 때문에 학생들의 학업성취도와 태도에 긍정적인 영 향을 미친다[18-20]. 그러므로 교수효능감은 교사의 미 래의 수업행동을 예측할 수 있는 변인으로 예비교사의 양성과정에서도 중요하게 고려될 필요가 있다.

예비교사를 대상으로 한 대부분의 교수효능감 연구 들은 교육실습이나 수업경험을 주된 변인으로 하고 있 다. 최승숙[8]은 특수학습 현장실습에서 예비특수교사 에게 반성적 저널쓰기를 하도록 한 결과 교수효능감이 증대되었다고 분석하였다. 정동욱[21]은 가상현실공간 에서의 모의수업실습이 예비교사의 개인적 교수효능감 에 영향을 미쳤지만, 결과기대감은 그대로였다고 지적 하였다. 박성혜[5]는 모의수업 기회로 중등 예비교사들 의 교수효능감이 긍정적으로 변화하였다고 보고하였다. 그러나, 이러한 연구들은 단순히 교육실습의 기회를 강조한 것만이 아니라, 그 과정에서의 학생들의 성찰을 동시에 강조하였다. 이남호[6], 임경식[7], 최승숙[8] 등 은 실습과정의 반성적 측면이 예비교사의 교수효능감 에 영향을 미쳤다고 지적하였다. 또한, 송수지[22]는 성 찰활동이 예비기독교사의 교수효능감 증진에 긍정적인 영향을 미쳤다고 제시하였다.

이러한 선행연구에 따르면 다양한 반성적 사고의 경 험이 예비교사의 교수효능감 증진에 기여하는 것으로 보인다. 따라서, 예비교사들의 전문성 향상과 교수효능 감 증진을 위해서는 교원양성교육과정에서 지속적이며 직간접적인 성찰의 기회를 제공해 주어야 한다. $\mathrm{e}^{-}$포트 폴리오의 활용은 예비교사들의 교육적 성찰을 돕는 효 과적인 방법이 될 수 있다.

이에 본 연구는 예비교사들에게 $\mathrm{e}-$ 포트폴리오를 활 용한 교육적 성찰 기회를 제공함으로써 이것이 교수효 능감 증진에 얼마나 기여하는지 그 효과를 확인해 보 고, 향후 교원양성교육에서 교수효능감을 증진에 기여 할 수 있도록 $\mathrm{e}^{-}$포트폴리오의 활용방법을 탐색해 보고 자 한다.

\section{III. 연구방법}

\section{1. 연구참여자}

본 연구는 수도권 $\mathrm{A}$ 대학교에서 교직과목을 수강하는 예비교사 42 명을 대상으로 약 10 주간 진행되었다. 이 중에서 교수효능감 사전검사나 사후검사에 참여하지 않거나 $\mathrm{e}-$ 포트폴리오 활용을 확인하기 어렵거나 검사 지의 응답수준이 불량한 7명의 자료를 제외하고 최종 적으로 35 명의 자료를 분석하였다[표 1].

\section{표 1. 연구참여자}

\begin{tabular}{|c|c|c|}
\hline \multicolumn{2}{|c|}{ 구분 } & 인원 \\
\hline \multirow{2}{*}{ 성별 } & 남자 & 3 \\
\cline { 2 - 3 } & 여자 & 32 \\
\hline \multirow{2}{*}{ 전공 } & 자연계 & 18 \\
\cline { 2 - 3 } & 인문계 & 17 \\
\hline \multirow{3}{*}{ 학년 } & 2학년 & 8 \\
\cline { 2 - 3 } & 3학년 & 9 \\
\cline { 2 - 3 } & 4학년 & 18 \\
\hline
\end{tabular}

\section{2. 연구절차}

$\mathrm{e}^{-}$포트폴리오의 활용이 예비교사들의 교수효능감에 미치는 영향을 알아보고 $\mathrm{e}^{-}$포트폴리오 활성화 전략을 제안하기 위하여 사전검사를 실시하고 10 주간 $\mathrm{e}^{-}$포트 폴리오를 운영하게 한 후에 사후검사와 인터뷰를 진행 하였다.

먼저 김아영과 김미진[23]의 교수효능감 측정 도구를 본 연구에 맞게 수정하여 예비교사 42 명에게 사전검사 를 실시하였다. 그리고 $\mathrm{e}-$ 포트폴리오 활용에 대한 간단 한 오리엔테이션을 진행하고, 이후 10 주 동안 매주 각 자의 전공 및 교육학 관련 자료를 2 개 이상 업데이트하 고, 매주 1 회 이상 제시된 성찰주제에 맞게 자유형식과 분량으로 일지를 작성하게 하였다. 두 개의 교직교과를 듣는 모든 학생들에게 $\mathrm{e}^{-}$포트폴리오 개발을 권장하였 으나, 성적과 결부되는 등의 강제적 조치는 없었으며 3 , 4 회 자료 작성을 독려하는 문자를 보냈다. 제시된 성찰 주제는 '교사가 되고 싶은 이유는 무엇입니까?', '학교교 육에서 교사의 능력이 학생의 학습능력에 얼마나 영향 을 미친다고 생각합니까? 그 이유는?, '좋은 교사란 누 구이며, 나는 좋은 교사가 되기 위해 어떤 점이 적절하 
고, 어떤 점이 부족합니까?', '자신이 생각하는 좋은 학 교교육이란 무엇입니까?' 등이었다.

10 주 후, 사전검사에 사용한 측정도구의 문항 순서를 변경하고 $\mathrm{e}-$ 포트폴리오의 사용소감 및 의견을 서술할 수 있는 질문을 추가하여 사후 교수효능감 검사를 진행 하였다. 그리고, $\mathrm{e}^{-}$포트폴리오 활용률이 비교적 높은 7 명과 활용률이 상대적으로 저조한 6 명의 예비교사를 대상 인터뷰를 진행하였다.

$\mathrm{e}^{-}$포트폴리오 활용 전과 후의 예비교사 교수효능감 을 비교하기 위해 SPSS 18.0.0을 이용하여 Wilcoxon의 부호순위통계량에 따라 대응표본의 차이를 비교하였 다. 사후 인터뷰 내용은 녹취 후 전사되었으며, 주제에 따라 다시 분류하여 분석하였다.

\section{3. 연구도구}

\section{1 교수효능감 측정도구}

본 연구에는 교수효능감 측정도구와 $\mathrm{e}^{-}$포트폴리오 도구 등 두 가지 도구가 사용되었다. 교수효능감 측정 도구는 중등교사의 업무전반에 있어서의 교수효능감을 측정하기 위한 김아영과 김미진[23]의 도구를 사용하였 다. 총 25문항으로 구성되었으며, 자신감, 자기조절효능 감, 과제난이도 선호의 세 가지 하위요소로 구성되어 있었다. 본 도구를 선택한 이유는 외국의 것들과 비교 해 보았을 때 문항의 기술이나 상황이 국내 교육현실을 반영하고 있어서 예비교사들에게 사용하기 적절하다고 판단하였기 때문이다.

본 연구는 예비교사를 대상으로 하기 때문에 문항의 일부를 예비교사의 상황에 맞게 미래형으로 수정하였 다. 예컨대, '학생들의 학업능력에 대한 나의 판단은 정 확하다'는 '학생들의 학업능력에 대한 나의 판단은 정확 할 것이다'로, '나는 문제 학생들을 지도하는 것을 좋아 한다'는 '나는 문제 학생들을 지도하는 데 열정을 쏟을 것이다'로 수정하였다.

본 연구도구는 5점 척도로 구성되었으며, 사전검사와 사후검사는 동일한 문항을 사용했으나, 그 순서를 무작 위로 변경하여 신뢰성을 높였다. 본 도구의 요소 및 전 체 신뢰도를 측정한 결과 .68에서 .88로 높은 편이었다 [표 2].

\section{표 2. 교수효능감 측정도구의 신뢰도}

\begin{tabular}{|c|c|c|c|}
\hline 하위요소 & 문항수 & 검사시기 & 신뢰도 \\
\hline \multirow{2}{*}{ 자신감 } & \multirow{2}{*}{7} & 사전검사 & .75 \\
\cline { 3 - 4 } & & 사후검사 & .82 \\
\hline \multirow{2}{*}{$\begin{array}{c}\text { 자기조절 } \\
\text { 효능감 }\end{array}$} & \multirow{2}{*}{11} & 사전검사 & .86 \\
\cline { 3 - 4 } & & 사후검사 & .84 \\
\hline \multirow{2}{*}{ 과제난이도 선호 } & \multirow{2}{*}{7} & 사전검사 & .68 \\
\cline { 3 - 4 } & & 사후검사 & .76 \\
\hline \multirow{2}{*}{ 전체 } & \multirow{2}{*}{25} & 사전검사 & .84 \\
\cline { 3 - 4 } & & 사후검사 & .88 \\
\hline
\end{tabular}

그 외에 사후검사도구에는 $\mathrm{e}$-포트폴리오의 유용성과 사용의 어려움, 교직에 대한 생각 변화 등 사용 경험과 관련된 개방형 설문문항이 포함되었다.

\section{2 e-포트폴리오 도구}

본 연구에 활용된 $\mathrm{e}$-포트폴리오는 $\mathrm{A}$ 대학교에서 제 공하는 것으로 별도의 가입절차 없이 학교포털과 동일 한 아이디로 로그인을 하면 개설이 가능하였다.

활용 측면에서 $\mathrm{e}$-포트폴리오의 특성은 다음과 같다. 첫째, 웹 기반의 블로그 형태로 모든 메뉴는 사용자가 원하는 대로 구성하고 편집할 수 있다. 둘째, 텍스트와 동영상 자료는 물론, 웹캠을 사용하여 실시간으로 프레 젠테이션을 녹화하여 업로드 할 수 있다. 셋째, 다른 사 용자의 포트폴리오를 구독하거나 자신의 글의 댓글을 확인하는 기능이 있어 상호작용성을 높였다.

$\mathrm{X}$ 사에서 개발하여 보급한 $\mathrm{e}^{-}$포트폴리오는 위젯 기반 으로 제작되었으며, 다양한 멀티미디어의 저작기능과 공유기능을 포함하고 있다. 각 게시물에 대해 개별적인 주소가 부여되며, 사용자가 메뉴 및 인터페이스를 변경 할 수 있도록 설계되었다. 또한, 팀 활동을 위한 덧글쓰 기 및 교수-학생 간, 학생-학생 간 상호작용을 지원하 였다. 이러한 일종의 블로그 기반의 통합형 $\mathrm{e}-$ 포트폴리 오는 상호작용적 학습을 촉진하고 포트폴리오의 학습 과 평가 기능을 통합하는 것이 특징이다[27]. 또한, 다 양한 유형의 자료제작을 지원하며, $\mathrm{e}^{-}$포트폴리오 사용 자 간의 상호작용 기능을 개선함으로써 개인 중심의 학 습지원도구인 포트폴리오를 협력적 학습을 지원하는 $\mathrm{e}^{-}$포트폴리오로 확장했다고 평가할 수 있다. 


\section{3 사후 인터뷰 도구}

사후 인터뷰는 $\mathrm{e}^{-}$포트폴리오 사용소감, $\mathrm{e}^{-}$포트폴리 오 활용이 교직에 미친 영향, $\mathrm{e}^{-}$포트폴리오의 장단점 및 향후 활용 방안 등에 관한 7 개 문항으로 구성되었다.

\section{IV. 연구결과}

\section{1. $\mathrm{e}$-포트폴리오 활용 결과}

약 10 주간 $\mathrm{e}^{-}$포트폴리오 활용현황을 살펴본 결과, 게 시물 수가 20개 이상인 학생이 7명, 10개에서 20개 미만 인 학생이 16 명, 10 개 미만인 학생이 12 명이었다. 가장 많은 글을 올린 학생의 게시물 수는 35 개였고, 가장 적 은 글을 올린 학생의 게시물 수는 1 개였다. 학생들이 평 균적으로 올린 게시물의 개수는 12.8 개였으며, 학년이 낮을수록 보다 열심히 $\mathrm{e}^{-}$포트폴리오 제작활동에 참여 하였다[표 3].

\section{표 3. 학년별 평균 $e-$ 포트폴리오 게시물 수}

\begin{tabular}{|c|c|c|c|c|}
\hline 학년 & 학생수 & 성찰일지 & 자료 & 총 게시물 \\
\hline 2학년 & 8 명 & 11.65 & 7.38 & 19.00 \\
\hline 3학년 & 9 명 & 9.11 & 4.67 & 13.78 \\
\hline 4학년 & 18 명 & 6.61 & 2.94 & 9.56 \\
\hline
\end{tabular}

$\mathrm{e}$-포트폴리오 활용 패턴을 분석해 보면, 대부분 성찰 일지는 주제에 따라 규칙적으로 작성된 경향이 있었으 나, 전공이나 교육학 관련 학습자료는 한꺼번에 올리는 경우가 많았다. 또한, 게시물의 형태는 텍스트가 가장 많았다.

\section{2. $\mathrm{e}$-포트폴리오 활용에 따른 교수효능감 변화}

$\mathrm{e}^{-}$포트폴리오의 활용 전과 후의 예비교사의 교수효 능감의 변화를 알아보기 위해 교수효능감의 평균을 비 교해본 결과, 전체 교수효능감의 평균은 $3.23(\mathrm{SD}=.38)$ 에서 3.46 $(\mathrm{SD}=.40)$ 로 증가하였다[표 4]. 세부요소별로 가장 많이 증가한 것은 과제난이도 선호로 평균0.31이 높아졌으며, 가장 낮은 것은 자기조절효능감으로 평균 0.14 가 증가하였다.
표 4. e-포트폴리오 활용 전후 교수효능감 평균 분석

\begin{tabular}{|c|c|c|c|}
\hline \multicolumn{2}{|c|}{ 구 분 } & 평균 & 표준편차 \\
\hline \multirow{2}{*}{ 전체 } & 사전 & 3.23 & .375 \\
\cline { 2 - 4 } & 사후 & 3.46 & .396 \\
\hline \multirow{2}{*}{ 자신감 } & 사전 & 2.51 & .479 \\
\cline { 2 - 4 } & 사후 & 2.80 & .540 \\
\hline \multirow{2}{*}{ 자기 } & 사전 & 3.72 & .476 \\
\cline { 2 - 4 } 조절 & 사후 & 3.86 & 401 \\
\hline 과제 & 사전 & 3.19 & .586 \\
\cline { 2 - 4 } 난이도 & 사후 & 3.50 & .559 \\
\hline
\end{tabular}

이러한 학생들의 자기효능감 변화가 유의미한지 확 인하기 위하여 대응표본 검정을 실시하였다. 참여자 수 가 35 명이어서 정규성 검정을 수행한 결과에 일부 통계 량에서 Kolmogorov-Smirnov와 Shapiro-Wilk를 활용 한 정규성 검정에 위배되어 $(\mathrm{p}<0.05)$, 비모수검정을 활 용해 Wilcoxon의 부호순위통계량에 따라 대응표본의 차이를 비교하였다. 그 결과 [표 5]와 같이 $\mathrm{e}^{-}$포트폴리 오 활용 전과 후 예비교사의 교수효능감에 통계적으로 유의미한 차이가 있는 것으로 분석되었다 $(\mathrm{p}<0.05)$.

\section{표 5. e-포트폴리오 활용 전후 교수효능감 차이 분석}

\begin{tabular}{|c|c|c|c|c|c|c|}
\hline \multicolumn{2}{|c|}{ 구분 } & $\mathrm{N}$ & 평균순위 & 순위합 & Z값 & p \\
\hline \multirow{3}{*}{$\begin{array}{c}\begin{array}{c}\text { 전체 } \\
\text { 사전-사후 }\end{array} \\
\end{array}$} & 음의순위 & 12 & 10.17 & 122.00 & \multirow{3}{*}{$-3.16^{* *}$} & \multirow{3}{*}{.002} \\
\hline & 양의순위 & 23 & 22.09 & 508.00 & & \\
\hline & 동률 & 0 & & & & \\
\hline \multirow{3}{*}{$\begin{array}{c}\text { 자신감 } \\
\text { 사전-사후 }\end{array}$} & 음의순위 & 11 & 9.50 & 104.50 & \multirow{3}{*}{$-2.64^{* *}$} & \multirow{3}{*}{.008} \\
\hline & 양의순위 & 19 & 18.97 & 360.50 & & \\
\hline & 동률 & 5 & & & & \\
\hline \multirow{3}{*}{$\begin{array}{c}\text { 자기 } \\
\text { 조절 } \\
\text { 사전-사후 }\end{array}$} & 음의순위 & 13 & 14.69 & 191.00 & \multirow{3}{*}{-1.83} & \multirow{3}{*}{.068} \\
\hline & 양의순위 & 21 & 19.24 & 404.00 & & \\
\hline & 동률 & 1 & & & & \\
\hline \multirow{3}{*}{$\begin{array}{c}\text { 과제 } \\
\text { 난이도 } \\
\text { 사전-사후 }\end{array}$} & 음의순위 & 7 & 14.64 & 102.50 & \multirow{3}{*}{$-3.35^{* *}$} & \multirow{3}{*}{.001} \\
\hline & 양의순위 & 27 & 18.24 & 492.50 & & \\
\hline & 동률 & 1 & & & & \\
\hline
\end{tabular}

사전-사후 교수효능감을 비교해 보면, 자신감과 과제 난이도 선호 부분에서 통계적으로 유의미한 차이가 있 었으나, 자기조절효능감의 경우 큰 차이를 보이지 않았 다. 하지만, 전체 교수효능감에서도 사전과 사후 유의미 한 변화를 보였다. 따라서, $\mathrm{e}^{-}$포트폴리오의 활용은 예 비교사의 교수효능감에 긍정적인 효과를 미치는 것으 로 나타났다. 


\section{3. $\mathrm{e}$-포트폴리오 활용이 예비교사의 교수효능감 에 미친 영향 분석}

개방형 설문과 인터뷰를 통해 $\mathrm{e}^{-}$포트폴리오가 예비 교사들의 교수효능감에 미친 영향을 분석하면 다음과 같다.

\section{1 예비교사로서 교수효능감 증진}

예비교사들은 대체적으로 $\mathrm{e}^{-}$포트폴리오의 성찰주제 에 대한 생각을 정리하면서 자신의 교직관에 대해서 되 돌아보고, 예비교사로서의 정체성을 확립할 수 있었다.

$\mathrm{e}$-포트폴리오 사용 전에는 교직 과목을 듣고는 있지 만 예비교사라는 실감이 안났다면, 지금은 예비교사로 서의 준비를 차근차근 해 나갈 수 있는 것 같아서 자신 감과 자부심이 커졌어요. (학생 14)

교육에 대한 이슈들이 생기면 그냥 방대한 양의 정보 만 받아들일 뿐이지 내 생각, 내가 저 상황이면 어떻게 할 것인지에 대한 것은 생각 해 본적이 없는데 성찰일지 를 통해서 진정한 교사가 되고 싶다는 동기부여가 된 것 같아요. (학생 6)

$\mathrm{e}^{-}$포트폴리오의 사용은 단순히 교사가 되는 것이 아 니라, 왜 교사가 되고 싶었는지, 그리고 좋은 교사가 되 기 위해서는 어떻게 해야 하는지 진지하게 생각해 볼 수 있는 기회를 제공하였다. 또한, 이러한 반성적 사고 를 통해 예비교사로서의 자신감과 자부심을 키우기도 하였다.

\section{2 교사의 업무에 대한 대리경험}

$\mathrm{e}$-포트폴리오를 활용하여 성찰일지를 쓰는 과정에서 예비교사들은 스스로 교사처럼 사고하면서 간접적이지 만 교사의 업무에 대한 대리경험을 하는 것으로 나타났 다.

$\mathrm{e}-$ 포트폴리오를 통해 학교와 학생, 선생님에 대해 더 깊이 있게 생각하고, 글을 쓰면서 실제 교사가 된 듯 한 느낌을 받아 더욱 더 교사가 되고 싶어졌어요.(학생 13)
앞으로 선생님이 되고 싶은데, 성찰을 하면서 학생들 을 어떤 방향으로 지도할 것인지, 만약 내가 지금 선생 님이 되었다면 어떻게 가르칠 것인지에 대해 미리 생각 해 볼 수 있는 기회가 되었어요. (학생 5)

Bandura는 이러한 대리경험을 자기효능감의 원천 중 하나라고 지적하였다[24]. 따라서 $\mathrm{e}^{-}$포트폴리오 작성 활동을 통한 교사업무에 대한 대리경험은 예비교사들 의 교수효능감 증진에 긍정적인 영향을 미칠 수 있다.

\section{3 단기적인 교수효능감 저하}

교직에 대한 진지한 성찰은 단기적으로 교수효능감 을 낮추기도 하였다. 학생들은 성찰활동을 통해 교직을 보다 진지하게 고려하기 시작했으며, 교사라는 직무의 중요성을 인식해 나가기 시작하였다.

처음에 교직 시작할 때에는 애들 앞에서 말 잘하고 재미있게 해주고 인간적인 관계만 잘 맺으면 된다고 생 각 $\cdots \mathrm{e}-$ 포트폴리오를 쓰면서 점점 더 교직이 어려워지 는 거 같아요.(학생 9)

학교현장이 결코 만만치 않겠구나...과연 내가 좋은 교사가 될 수 있을까?라는 생각도 해 보게 되는 것 같아 요. 나한테 교직이 맞는지 잘 할 수 있는지에 대해 생각 이 깊어지는 것 같아요. (학생 28)

따라서 교원양성교육과정에 이러한 단기적인 교수효 능감 저하를 극복하도록 하기 위한 방안을 모색할 필요 가 있다.

\section{4 진로의 전환}

일부 학생들은 $\mathrm{e}^{-}$포트폴리오를 활용한 성찰을 계기 로 자신의 진로가 교직이 아니라 다른 것임을 명확하게 인식할 수 있었다.

내 생각을 정리함으로써 보다 분명하고 객관적으로 알아볼 수 있었습니다. 교직이 마음에 들고 너무 좋았지 만 생각들을 정리하면서 더 하고 싶은 일들이 존재하고 있음을 발견할 수 있었습니다.(학생 20) 
이와 같이 $\mathrm{e}^{-}$포트폴리오를 활용한 반성적 성찰과정 은 예비교사들로 하여금 교직과 미래의 진로에 대해 보 다 진지하게 생각하도록 유도함으로써 교수효능감의 변화에 영향을 미쳤다.

\section{4. e-포트폴리오 활용에 대한 긍정적 · 부정적 인 식 분석}

예비교사들은 $\mathrm{e}^{-}$포트폴리오가 학습에 긍정적인 효과 를 미친다고 인식하였다. 그러나, 기술적 측면에서 몇 가지 부정적인 인식도 드러내었다.

\section{$4.1 \mathrm{e}$-포트폴리오 활용에 대한 긍정적 인식}

예비교사들이 지적한 $\mathrm{e}^{-}$포트폴리오의 긍정적인 효과 는 크게 세 가지로 정리할 수 있다.

첫째, $\mathrm{e}$-포트폴리오에 남긴 기록을 통해 자신의 발전 을 확인함으로써 교수효능감을 높였을 뿐만 아니라, 예 비전문가로서 자기 개발을 위한 방향을 설정하는데 활 용하였다.

둘째, $\mathrm{e}^{-}$포트폴리오에 학습에 대한 성찰과 학습용 자 료들을 탑재합으로써 단기적으로 학습을 촉진하는 수 단으로 활용하였다. 수업 후의 자료정리나 인터넷에서 수집한 전공 관련 자료를 $\mathrm{e}^{-}$포트폴리오에 저장하는 과 정은 자연히 학습으로 연결되었다.

셋째, $\mathrm{e}^{-}$포트폴리오는 교수나 동료 예비교사와의 상 호작용을 증진시키는 역할도 하였다. 수업의 확장이라 는 면에서 이 측면을 효과적으로 사용하면 교육적 효과 가 클 것으로 보인다.

이 외에도 '글쓰기 능력의 향상', '생각을 정리하는 기 회 확보', '공부하는 습관' 등을 장점으로 들었다. 이러 한 $\mathrm{e}^{-}$포트폴리오 활용에 대한 긍정적인 인식들은 앞서 선행연구에서 지적된 $\mathrm{e}^{-}$포트폴리오의 교육적 효과와 상당부분 유사하다.

\section{$4.2 \mathrm{e}$-포트폴리오 활용에 대한 부정적 인식}

예비교사들은 $\mathrm{e}^{-}$포트폴리오에 대해 긍정적인 인식과 함께 부정적인 인식도 내보였다. 부정적인 인식은 크게 네 가지로 정리할 수 있다.
첫째, 예비교사들은 처음 $\mathrm{e}^{-}$포트폴리오를 작성하는 단계에서 어렵고 배우는데 노력이 필요하다고 생각하 였다. 무엇보다 기술적인 측면의 어려움을 지적하였다. 또한, 기술적인 문제가 없다고 하더라도 어떤 내용을 어떻게 올려야 하는지 구체적인 교육적 활용방법에 대 한 안내와 관리를 필요로 했다.

둘째, 개인 블로그를 운영하는 예비교사들에게는 접 근성이 떨어지는 중복된 블로그를 운영하는 것과 같이 번거롭거나 불편하다는 느낌을 주었다. $\mathrm{e}^{-}$포트폴리오 가 블로그식으로 개발되었기 때문에 사용성 측면에서 학생들에게 친숙하게 다가서는 장점은 있었으나, $\mathrm{e}^{-}$포 트폴리오만의 고유한 정체성을 인식시키는 데는 오히 려 방해가 되기도 하였다.

셋째, 일부 예비교사들은 개인정보 노출을 우려하고, 개인적 성찰내용을 공개하는 것을 부담스럽게 생각하 였다. 특히 블로그를 개인적으로 운영하지 않는 예비교 사들은 이러한 경향이 더욱 심하였다. 이것은 $\mathrm{e}^{-}$포트폴 리오를 처음 사용한 교수들도 가장 심각하게 느끼는 문 제였다[11].

넷째, $\mathrm{e}^{-}$포트폴리오의 기술적 측면이나 교육적 측면 에서의 불만은 아니지만, 활용 과정에서 활용자 수가 적은 것이 예비교사들의 참여를 저하시키는 원인이 되 기도 하였다. 일부 예비교사들은 $\mathrm{e}$-포트폴리오를 통해 교수 및 학생들과 적극적인 상호작용이 이루어지지 않 은 것이 $\mathrm{e}^{-}$포트폴리오 사용 의욕을 저하시켰다고 지적 하였다.

$\mathrm{e}^{-}$포트폴리오 활용 정도가 예비교사 간 큰 차이가 있 었던 것은 이러한 부정적인 인식이 작용했기 때문이라 고 예상할 수 있다. 따라서 부정적인 인식을 극복할 수 있는 전략을 마련한다면, 교육적 용도로 $\mathrm{e}^{-}$포트폴리오 사용을 활성화하는데 기여할 수 있을 것이다.

\section{V. 결론}

본 연구는 $\mathrm{e}^{-}$포트폴리오를 활용한 성찰활동이 예비 교사의 교수효능감에 미친 영향과, $\mathrm{e}^{-}$포트폴리오에 대 한 예비교사들의 인식을 살펴보는 것을 목적으로 하였 
다. $\mathrm{e}^{-}$포트폴리오 사용 전후 교수효능감의 차이를 분 석한 결과, 전체적으로 예비교사들의 교수효능감이 증 가한 것으로 나타났다. 그러나, 인터뷰 및 개방형 설문 을 통해 확인한 결과, 성찰활동이 예비교사로서의 정체 성을 확립하고 미래 교사로서의 대리경험을 하는데 도 움을 주기도 하였지만, 교직을 보다 진지하게 생각해 보는 기회를 제공해 주고 자신의 적성을 반추하게 함으 로써 오히려 교수효능감을 저하시키기도 하였다. 그러 나, 이러한 결과들은 모두 예비교사로 하여금 교직에 대해 깊이 있게 성찰해 보는 기회를 제공해주었다는 점 에서 의미가 있다고 할 수 있다.

예비교사들의 교수효능감을 증진시키기 위한 $\mathrm{e}^{-}$포트 폴리오의 활성화 방안을 제시하면 다음과 같다.

첫째, 교직입문 초기부터 예비교사들이 지속적으로 $\mathrm{e}$-포트폴리오를 작성할 수 있도록 교원양성교육과정의 일부에 포함하여야 한다. 지속적인 $\mathrm{e}-$ 포트폴리오 작성 은 교직 입문자들이 자신의 흥미와 적성이 교사라는 직 업에 적합한지 깊이 있게 사고하는 기회를 제공함으로 써 빠른 진로 결정을 도우며, 예비교사로서 성장을 유 도할 수 있다. 따라서 예비교사들을 대상으로 $\mathrm{e}^{-}$포트폴 리오 활용교육을 실시하고, 중간 중간 활용 상태를 점 검하며, 적절한 활용방법에 대한 안내를 제공할 필요가 있다.

둘째, 예비교사들이 피상적인 수준의 교직관을 갖는 것이 아니라, 현실적인 교육문제에 대해서 진정으로 숙 고함으로써 교직에 대한 대리경험을 할 수 있도록 지원 할 필요가 있다. 이를 위해 학습자의 선수지식과 관심 을 고려하여 적절한 수준에서 교사의 실제 업무나 교육 문제와 관련된 성찰주제를 지속적으로 제공해 주는 것 이 효과적이다[14]. 효과적인 성찰을 유도하기 위해서 는 효과적인 글쓰기에 대한 교육도 필요하다. 자신의 생각을 표현함으로써 객관적으로 스스로를 바라보는 것에 대해서 훈련할 필요가 있다. 또한, 학생들이 개인 블로그와 다른 $\mathrm{e}^{-}$포트폴리오의 정체성을 명확히 인식 할 수 있도록 유도할 필요도 있다.

셋째, 예비교사들이 스스로의 성장과정을 확인할 수 있도록 하기 위해 교육과정에서 산출물을 꾸준히 탑재 하도록 유도해야 한다. 교직 입문 초기부터 산출물을
축적하는 활동은 학생으로서 예비교사들의 학습을 증 진시킬 뿐만 아니라, 예비교사 스스로 축적된 산출물들 을 통해 자신의 발전을 확인함으로써 교수효능감을 높 이는데 기여할 수 있다. 또한, 축적된 자료는 추후 교생 실습이나 모의수업에서 효과적인 자료로 활용될 수 있 다.

넷째, 개별적 학습을 넘어서 협력적 학습이 이루어질 수 있도록 다양한 $\mathrm{e}$-포트폴리오의 활용방법을 개발할 필요가 있다. 특히 예비교사들은 미래의 교사로서 다양 한 수업모형과 환경을 경험하는 것이 이들의 발전에 도 움이 된다. 따라서, $\mathrm{e}^{-}$포트폴리오를 활용한 다양한 교 수학습방법과 전략을 개발-보급하여 예비교사를 대상 으로 하는 수업에서 활용할 수 있도록 유도할 필요가 있다.

마지막으로 교수효능감과 직접적인 관련은 없지만 학생들의 접근성을 높이기 위한 모바일 서비스 제공, 학습자의 이력과의 연동 강화, 개인 블로그와의 호환, 정보공개 범위 설정의 정교화 등 $\mathrm{e}^{-}$포트폴리오의 기술 적인 측면에서 보완이 필요하다.

최근 많은 대학에서 $\mathrm{e}^{-}$포트폴리오의 도입을 시도하 고 있다. $\mathrm{e}$-포트폴리오를 통한 성찰 활동은 예비교사들 의 교수효능감을 높이며, 이들이 스스로의 성장과정을 확인할 수 있도록 도울 뿐만 아니라, 학습을 위한 유용 한 보조 도구로 활용될 수 있다. 본 연구는 예비교사 양 성과정에서 교수효능감을 증진시킬 수 있는 방안으로 $\mathrm{e}^{-}$포트폴리오의 활용을 제안하였다. 그러나, 연구참여 자의 수가 제한되었으며, 참여자들의 교육효과를 고려 하여 비교집단을 설정하지 못했다는 점이 연구의 한계 로 지적될 수 있다. 본 연구에서 제안된 $\mathrm{e}^{-}$포트폴리오 의 활성화 전략도 향후 추가적인 연구를 통해 교육현장 에 맞게 구체화될 필요가 있다.

\section{참 고 문 헌}

[1] P. T. Ashton, "Teacher efficacy: A motivational paradigm for effective teacher education," Journal of Teacher Education, Vol.35, pp.28-32, 
1984.

[2] M. Tschannen-Moran and A. W. Hoy, "Teacher efficacy: Capturing an elusive construct," Teaching and Teacher Education, Vol.17, pp.783-805, 2001.

[3] A. W. Hoy and R. B. Spero, "Changes in teacher efficacy during the early years of teaching: A comparison of four measures," Teaching and Teacher Education, Vol.21, No.4, pp.343-356, 2005.

[4] W. K. Hoy and A. E. Woolfolk, "Socialization of student teachers," American Educational Research Journal, Vol.27, pp.279-300, 1990.

[5] 박성혜, “중등 교사양성과정 중 <교과교재연구 및 지도법>이 예비교사들의 교수효능감과 교과 교육학지식에 미치는 영향”, 한국교원교육연구, 제25권, 제1호, pp.209-233, 2008.

[6] 이남호, "반성적 교육실습을 통한 예비교사의 교 사 효능감 변화”, 부산교육학연구, 제 20 권, 제 1 호, pp.105-119, 2007.

[7] 임경심, 유치원 교육실습에서 반성적 저널쓰기가 예비교사의 교육신념 및 교사효능감에 미치는 영 향, 전남대학교 석사학위논문, 2009.

[8] 최승숙, “반성적 저널쓰기를 활용한 특수학급 현 장실습이 예비특수교사의 교사효능감에 미치는 영향”, 특수교육, 제11권, 제1호, pp.107-130, 2012.

[9] M. Jone, "Transformational learners: Transformational Teachers," Australian Journal of Teacher Education, Vol.34, No.2, Available at: http://ro.ecu.edu.au/ajte/vol34/iss2/2

[10] 임승렬, “교사교육에서 포트폴리오 개발과 활 용”, 한국교사교육, 제17권, 제1호, pp.315-335, 2000 .

[11] 신종호, 홍성연, "혁신저항이론에 근거한 대학 교수의 $\mathrm{e}^{-}$티칭포트폴리오 이용 활성화 방안 탐 색”, 2013년 한국교육정보미디어학회 춘계학술대 회 발표 논문집, 2013.

[12] R. Edgerton, P. Hutchings, and K. Quinlan, The teaching portfolio: Capturing the scholarship of teaching, American Association for higher Education, 1991.

[13] 이영석, 이정화, 영역별 포트폴리오 평가방법의 적용 원리와 실제, 교육과학사, 2000.

[14] 이은화, "중등 예비교사를 위한 국제이해교육 과 목의 $\mathrm{e}^{-}$티칭 포트폴리오 개발 및 적용”, 컴퓨터교 육학회논문지, 제14권, 제5호, pp.55-69, 2011.

[15] 엄미리, 박인우, "e-포트폴리오 성찰일지 작성활 동의 학습효과에 영향을 미치는 학습자 관련 변 인 탐색”, 교육공학연구, 제27권, 제1호, pp.213-246, 2011.

[16] 한안나, “예비교사의 학습성향이 $\mathrm{e}^{-}$포트폴리오 활용에 미치는 영향”, 교사교육연구, 제 51 권, 제3 호, pp.471-487, 2012.

[17] 심미자, 설양환, “예비교사의 교육정보화 능력 향상을 위한 $\mathrm{e}^{-}$티칭 포트폴리오 활용 방안”, 교육 정보미디어연구, 제13권, 제1호, pp.309-329, 2007.

[18] S. Gibson and M. Dembo, "Teacher efficacy: A construct validation," Journal of Educational Psychology, Vol.76, No.4, pp.569-582, 1984.

[19] L. G. Enochs and I. M. Riggs, "Further development of an elementary science teaching efficacy belief instrument: preservice elementary scale," School Science and Mathematics, Vol.90, No.8, pp.694-706, 1990.

[20] K. Tobin, D. Tippins, and A. Gallard, "Research on instructional strategies for teaching science," In D. L. Gabel (Ed.), Handbook of research on science teaching and learning, Macmillan, pp.45-93, 1994.

[21] 정동욱, 가상현실공간에서의 수업실습이 예비교 사의 교수효능감에 미치는 영향, 한국교원대학교 박사학위논문, 2010.

[22] 송수지, “성찰활동이 예비기독교사의 교수효능 감 및 학업적응에 미치는 효과”, 한국기독교교육 학회, 제32권, pp.237-265, 2012.

[23] 김아영, 김미진, “교사효능감 척도 타당화”, 교육 
심리연구, 제18권, 제1호, pp.37-58, 2004.

[24] A. Bandura, "Self-efficacy: Toward a unifying theory of behavioral change," Psychological Review, Vol.84, No.2, pp.191-215, 1997.

[25] 박동진, 이회복, 윤준상, 박상태, 서정아, 이윤정, "대학생 학습역량 강화를 위한 $\mathrm{e}^{-}$포트폴리오 구 축 사례 연구”, 한국콘텐츠학회 2012 춘계종합학 술대회, pp.207-208, 2012.

[26] 강인애, 유승현, 강연경, "학습성찰도구로서 $\mathrm{e}^{-}$ 포트폴리오 활성화를 위한 연구: 경희대학교 사 례를 중심으로”, 한국콘텐츠학회논문지, 제 11 권, 제2호, pp.495-506, 2010.

[27] 김상수, 김영학, “국내 초·중등학교의 포트폴리 오 활용 실태 분석에 기반한 $\mathrm{e}^{-}$포트폴리오 설계 방향에 관한 연구”, 한국콘텐츠학회논문지, 제7 권, 제12호, pp.83-94, 2007.

[28] A. M. Brenner and M. M. Jennifer, "Evaluating the instructional effectiveness of one college's pre-service teacher $\mathrm{e}^{-}$-portfolio development process," The Teacher Educators Journal, Vol.18, pp.11-25, 2011.

[29] 이수연, $e^{-}$포트폴리오의 활용이 예비교사의 교 수효능감에 미치는 영향, 아주대학교 석사학위논 문, 2013.

\section{저 자 소 개}

이 수 연(Sooyeon Lee)

정회원

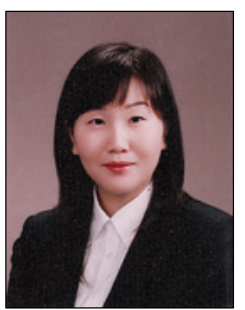

- 2004년 2월 : 중앙대학교 중어학 과(문학사)

- 2013년 8월 : 아주대학교 교육대 학원 교육학과(교육학석사)

<관심분야> : 학습 테크놀로지, 교육수월성, 이러닝
홍 성 연(Seongyoun Hong) 정회원

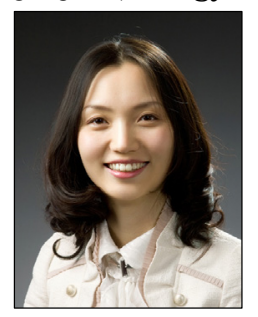

- 1998년 2월 : 연세대학교 사학 과(문학사)

- 2001년 2월 : 서울대학교 대학 원 역사교육과(교육학석사)

- 2009년 2월 : 서울대학교 대학 원 교육학과(교육학박사)

- 2012년 3월 현재 : 아주대학교 기초교육대학 대우 조교수

<관심분야> : 학습자지원, 역량, 교육수월성, 이러닝 